\title{
Hemorrhagic ascites endometriosis could be a cause: a case report
}

\author{
Nadia Abdelaaty Abdelkader ${ }^{1,2}$, Ahmed F. Sherief ${ }^{1}$, Enass Mohamed Soliman ${ }^{1 *}$, Mahmoud Elsamman ${ }^{3}$, \\ Salah T. Fayed ${ }^{4}$ and Mohamed A. Sakr ${ }^{1}$
}

\begin{abstract}
Background: Endometriosis is a condition in which tissue similar to the lining inside the uterus (called "the endometrium") is found outside the uterus, where it induces a chronic inflammatory reaction that may result in scar tissue. Endometriosis with massive ascites causing abdominal distension and other symptoms simulating malignancy has been described in the literature.

Case presentation: A case of a 27-year-old woman who presented to the Ascites Study Group Tropical Medicine department Ain Shams University in collaboration with the Egyption Club of Ascites (ECA) with increased central abdominal contour, shifting dullness, and hemorrhagic transudate hypocellular ascites with no malignant cells and bilateral ovarian cysts.

A long stepwise approach was conducted to the patient, and after exclusion of other causes of hemorrhagic ascites, the patient was prepared for laparoscopy.

The diagnosis of endometriosis was made.

The patient was discharged on goserelin acetate subcutaneous injection every 28 days with good response, and she regularly follows up with our study group on scheduled visits monthly according to her clinical status.
\end{abstract}

Conclusions: Endometriosis could be a possible cause of massive hemorrhagic obscured ascites.

The unexplained infertility should increase the probability of the endometriosis.

Keywords: Ascites, Endometriosis, Infertility, Ovarian cyst, Case report

\section{Background}

Endometriosis is a condition in which tissue similar to the lining inside the uterus (called "the endometrium") is found outside the uterus, where it induces a chronic inflammatory reaction that may result in scar tissue [1]. It is primarily found on the pelvic peritoneum, on the ovaries, in the recto-vaginal septum, on the bladder, and bowel $[2,3]$.

In very rare cases it has been found on the diaphragm and in the lungs [4].

\footnotetext{
*Correspondence: enasssoliman91@gmail.com

${ }^{1}$ Department of Tropical Medicine, Faculty of Medicine, Ain Shams

University, Cairo, Egypt

Full list of author information is available at the end of the article
}

Endometriosis affects an estimated 1 in 10 women during their reproductive years (i.e., usually between the ages of 15 and 49), which is approximately 176 million women in the world $[5,6]$.

Moreover, the diagnosis of extra-pelvic endometriosis is even more difficult given the variety of symptoms, signs, and locations [7]. Although in some instances, endometriosis can be diagnosed noninvasively, difficulty may be encountered in patients who lack typical symptoms or radiographic signs.

Hemorrhagic ascites due to endometriosis is an exceedingly uncommon diagnosis rarely reported in the medical literature [8]. 
Endometriosis with massive ascites causing abdominal distension and other symptoms simulating malignancy has been described in the literature [9-11].

\section{Case presentation}

We present a case of a 27-year-old woman who presented to the Ascites Study Group Tropical Medicine department Ain Shams University in collaboration with Egyptian Club of Ascites (ECA) for abdominal enlargement and was found with increased central abdominal contour, shifting dullness, and hemorrhagic transudate hypocellular ascites with no malignant cells and bilateral ovarian cysts. This picture was suggestive of an ovarian hyper-stimulation syndrome. There is no history of the problematic menstrual cycle, but she was infertile for 6 years of an unknown obvious cause. A long stepwise approach was conducted to the patient and after exclusion of other causes of hemorrhagic ascites, the patient was prepared for laparoscopy. And the result showed that there is grade III to IV pelvic endometriosis and right ovarian endometrioma, left ovarian surface lesion that was biopsied also, perihepatic adhesions and encysted peritoneal adhesions in Douglas pouch, and its wall was biopsied too. The ovarian biopsy didn't show any abnormality and the adhesion wall biopsy revealed hyalinized fibrovascular connective tissue. The patient was discharged on goserelin acetate subcutaneous injection every 28 days with good response and she regularly follows up with our study group on scheduled visits monthly according to her clinical status.

\section{Discussion}

Endometriosis affects an estimated 1 in 10 women during their reproductive years $[5,6]$. Concern recent review and analysis of previous cases found that $63 \%$ of women were of African ancestry, and $82 \%$ were nulliparous [12]. However, the difficulty to reach a definite diagnosis is related to the other late presentable causative diseases such as tuberculosis, pelvic malignancy, and peritoneal metastases. Therefore, to reach the diagnosis, an invasive maneuver is mandatory especially in the absence of typical presentation related to endometriosis. The Definitive management consists of surgical resection of endometriotic tissue alone or combined with the complete surgery (hysterectomy with oophorectomy) or long-term hormonal suppression therapy [13]. In young multi-parous patients, it is preferred to use long-term hormonal suppressive therapy to preserve fertility in some cases.

\section{Conclusions}

Endometriosis could be a possible cause of massive hemorrhagic obscured ascites. Hemorrhagic ascites should be considered a complication of endometriosis, especially in nulliparous women of the childbearing age group with an abdominal distension, a pelvic mass, dysmenorrhea, and abdominal pain, even if there is no typical presentation of the endometriosis along the menstrual history of the case.

\begin{abstract}
Acknowledgements
Not applicable

Authors' contributions

NA analyzed and interpreted the patient data regarding the hepatological and radiological findings and read and approved the final manuscript. AF collected the data and followed up with the patients clinically. ES was a major contributor in writing the manuscript. MS read and approved the final manuscript. ST analyzed and interpreted the patient data regarding the gynecological disease. MAS analyzed and interpreted the patient data regarding the hepatological and radiological findings. The author(s) read and approved the final manuscript.
\end{abstract}

Funding

No funding was received.

Availability of data and materials

Not applicable

\section{Declarations}

Ethics approval and consent to participate

Not applicable

Consent for publication

Written consent to publish this information was obtained from study participants.

Competing interests

The authors declare that they have no competing interests.

\section{Author details}

${ }^{1}$ Department of Tropical Medicine, Faculty of Medicine, Ain Shams University, Cairo, Egypt. ${ }^{2}$ Founder of the Egyptian Club of Ascites (ECA), Cairo, Egypt. ${ }^{3}$ Department of Internal medicine, Faculty of Medicine, Sohag University, Sohag, Egypt. ${ }^{4}$ Obstetrics and Gynecology Department, Faculty of Medicine, Ain Shams University, Cairo, Egypt.

Received: 28 May 2021 Accepted: 25 June 2021

Published online: 27 November 2021

\section{References}

1. Bulletti C, Coccia ME, Battistoni S, Borini (2010) Endometriosis and infertility. J Assist Reprod Gene 27(8):441-447. https://doi.org/10.1007/ s10815-010-9436-1

2. Kennedy S, Bergqvist A, Chapron C, D'Hooghe T, Dunselman G, Greb R et al (2005) ESHRE guideline for the diagnosis and treatment Of endometriosis. J Human Reprod 20(10):2698-2704. https://doi.org/10.1093/ humrep/dei135

3. Giudice LC (2010) Endometriosis. Clinical Practice. N Engl J Med 362(25):2389-2398

4. Sonavane SK, Kantawala KP, Menias CO (2011) Beyond the boundariesendometriosis: typical and atypical locations. J Curr Probl Diagn Radiol 40:219-232 
5. Rogers PA, D'Hooghe TM, Fazleabas A, Gargett CE, Giudice LC, Montgomery GW et al (2009) Priorities for endometriosis research: recommendations from an international consensus workshop. J Reprod Sci 16(4):335346. https://doi.org/10.1177/1933719108330568

6. Adamson GD, Kennedy S, Hummelshoj L (2010) Creating solutions in endometriosis: global collaboration through the WORLD ENDOMETRIOSIS Research Foundation. J Endometriosis 2(1):3-6. https://doi.org/10. 1177/22840265100020010

7. Jubanyik KJ, Comite F (1997) EXTRAPELVIC endometriosis. Obstet Gynecol Clin North America 24(2):411-440. https://doi.org/10.1016/ s0889-8545(05)70311-9

8. Varun N, Tanwar R (2017) A rare presentation of endometriosis with massive haemorrhagic ascites: a case report. Gynecol Obstetr Case Rep 03(01). https://doi.org/10.21767/2471-8165.1000047

9. Schlueter FJ, McClennan BL (1994) Massive ascites and pleural effusions associated with endometriosis. Abdominal Imaging 19(5):475-476. https://doi.org/10.1007/bf00206945
10. Jose R, George S, Seshadri L (1994) Massive ascites associated with endometriosis. Int J Gynecol Obstetr 44(3):287-288. https://doi.org/10.1016/ 0020-7292(94)90185-6

11. Spitzer M, Benjamin F (1995) Ascites due TO Endometriosis. Obstetr Gynecol Survey 50(8):628-631. https://doi.org/10.1097/00006254-19950 8000-00024

12. Mejia EM, Alvarez OA, Lee M (1997) Endometriosis with massive bloody ascites. JABFP 10:1

13. Ussia A, Betsas G, Corona R, De Cicco C, Koninckx P (2008) Pathophysiology of cyclic hemorrhagic ascites and endometriosis. J Minimally Invasive Gynecol 15(6):677-681. https://doi.org/10.1016/j.jmig.2008.08.012

\section{Publisher's Note}

Springer Nature remains neutral with regard to jurisdictional claims in published maps and institutional affiliations.

\section{Submit your manuscript to a SpringerOpen ${ }^{\circ}$ journal and benefit from:}

- Convenient online submission

- Rigorous peer review

- Open access: articles freely available online

- High visibility within the field

- Retaining the copyright to your article

Submit your next manuscript at $\boldsymbol{\nabla}$ springeropen.com 